\title{
解説
}

\section{ネットワークの 中立性と競争政策}

谷脇康彦 Yasuhiko Taniwaki 総務省情報通信国際戦略局情報通信政策課

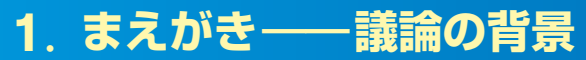

我が国の固定ブロードバンド加入数は 2,934 万加入 (2008 年 6 月末現在).世界で最も速くて安いブロードバン ド環境が実現している.

ブロードバンド化や IP（Internet Protocol）化が進展する と, 市場の統合化が進む。従来の通信市場は, 音声 . データ・映像というサービスごとのネットワークが構築されて いたが，IP 化によって，こうしたサービスに色づけされたネッ トワークの違いがなくなってきている. これは市場の水平統合 (horizontal integration)と呼ばれる.

他方, 従来の電話網の場合は発信者から着信者までエン ドエンドベースで電話会社が運用してきたが，IP 化が進展 する中, 近年のビジネスモデルは複数のレイヤを縦断するも のが出てきた.

ブロードバンド時代の事業モデルを分析するには, レイヤ 型の分析の枠組みを用いることが有益である. 具体的に

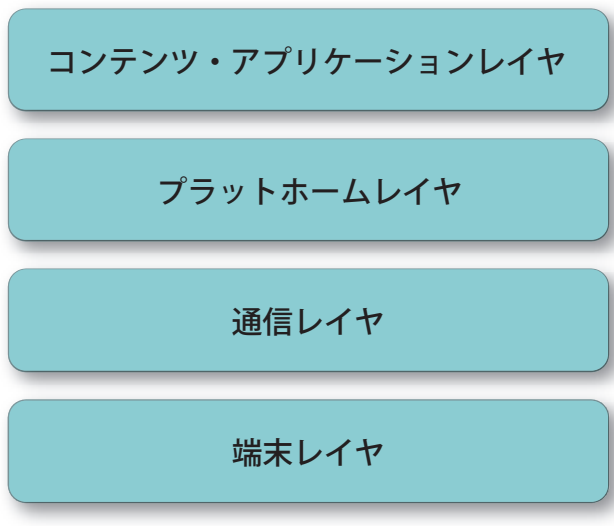

ブロードバンド時代の事業モデルは，4 層のレ イヤ構造で分析することが望ましい.

図 1 レイヤ図
は，端末レイヤ，通信レイヤ（通信ネットワークと通信サービ ス）,プラットホームレイヤ（認証・課金機能, QoS（Quality of Service）制御機能など), コンテンツ・アプリケーションレイ ヤの四つのレイヤに分ける(図 1).

例えばアップル社の iPod のビジネスモデルでは，まず iPodという端末を販売する. 利用者は自分の PCにダウン ロードした無料のソフトウェア“iTune”を使って, iPod に楽曲 をダウンロードする。通信レイヤの部分をアップル社は提供し ない. プラットホームレイヤには iTune Store というポータルを 作り, 認証・課金の機能を提供する。 そして, このポータル の上に楽曲などのコンテンツを集めてきて販売している. まさ に, 端末レイヤから（通信レイヤを中抜きして)プラットホーム レイヤ, 更にコンテンツ・アプリケーションレイヤまで縦断する モデル，つまり垂直統合（vertical integration）型のビジネス モデルを構築している.

垂直統合型のビジネスモデルでは, すべてのレイヤを単 一の事業体が提供する必要はない. アップル社のビジネス モデルもまさにそうであり，各レイヤで得意とする経営資源を 持ち寄って, いわばマッシュアップする形で垂直統合型のビ ジネスモデルを構築することが可能になっている.

こうした市場の水平統合や垂直統合が進むと, 複数のプ レーヤのコラボレーションによってさまざまなビジネスモデルを 構築することが可能となる. しかし, 利用者からすると, 何 か不具合が発生した場合に，だれが責任を持ってサービス を提供しているのか，自分はだれに不具合の相談をすれば よいのかということが分かりにくくなる. また, コラボレーション による自由なマッシュアップがしくみ上可能になったとしても, 市場で競争力のある通信事業者が自分と資本関係にある プレーヤだけを優遇して, 競争しているプレーヤを不利な立 場に追い込む差別的な取扱いをする可能性もある。 
通信分野の競争政策は，これまで通信レイヤのプレーヤ(通 信事業者）が公正な条件で競争できる環境を整えることが基 本であったが, ブロードバンド化・IP 化に伴う市場統合が起こ ると, 通信事業者, ISP (Internet Service Provider), コンテン ツプロバイダなど，複数の関係者で構成するマルチステークホ ルダ (multi stakeholder) 環境の中で, 垂直方向に見た公正 競争をどのように確保するかという視点が新たな検討課題とし て浮上してきたのである.

\section{2.ネットワークの中立性とは何か}

ネットワークの中立性（network neutrality）を巡る議論は, こうしたマルチステークホルダ環境の中でネットワーク環境を いかに公正中立なものとして維持していくかというものである.

ネットワークの中立性は, 総務省「ネットワークの中立性に 関する懇談会」報告書 (2007 年 10 月) を踏まえ，以下の 3 項目が原則として整理されている(総務省「新競争促進プロ グラム 2010」(2007 年 10 月改定)).

（a）消費者がネットワーク(IP 網)を柔軟に利用して, コン テンツ・アプリケーションレイヤに自由にアクセス可能で あること。

（b）消費者が技術基準に合致した端末をネットワーク（IP 網)に自由に接続し，端末間の通信を柔軟に行うことが
可能であること.

（c）消費者が通信レイヤ及びプラットホームレイヤを適正 な対価で公平に利用可能であること.

以上の三つの原則は, いずれもレイヤ間相互の公平性確 保を意罒したものであり, 消費者 (エンドユーザ) から見て垂 直方向の公正競争を確保するためのベンチマーク的な位 置付けとなっている.

ネットワークの中立性を上記の 3 原則に沿って確保して いく際，己れだけでは抽象的であり，実際の政策展開に際 しては「具体的な視点」が必要となる. 上記の懇談会報告 書では，これを「ネットワークのコス卜負担の公平性」と「ネット ワークの利用の公平性」の二つに分けている. 前者は近年 のネットワーク混雑の加速化に関係しており, 後者はNTT 東西が商用サービスを開始した NGN（Next Generation Network ; 次世代通信網)や移動通信市場における事業モ デルのあり方などと関係している. 以下，それぞれの議論に ついて見ていくこととしたい.

\section{3. ネットワークのコスト具担の公平性}

\section{1）ネット混雑の進展}

我が国は世界有数のブロードバンド大国であるが, そうで あるがゆえに，世界で最初に直面する問題が出てきている.

ロインターネット利用環境の整備

・FTTH 利用が急速に浸透.

・利用者一人当たりのトラヒックが 3 年で 2 倍に増加.

・動画などのリッチコンテンツが増加し利用しやすくなった。

・P2P 利用が拡大.

・インターネット利用者の増加以上に，利用トラヒックの 伸びが大きい

\begin{tabular}{|c|c|c|c|}
\hline & 2004 年 * & 2007 年 * & 伸び率 \\
\hline $\begin{array}{l}\text { A.トラヒック総量 }(a) \\
\text { (総務省「我が国のインーネットにおける } \\
\text { トラヒックの集計・試算」より) }\end{array}$ & $323.6 \mathrm{Gbit} / \mathrm{s}$ & $812.9 \mathrm{Gbit} / \mathrm{s}$ & 2.51 倍 \\
\hline $\begin{array}{l}\text { B.PC からのインターネット利用者数 }(b) \\
\text { (総務省「ブロードバンドサービスの契約数等」, } \\
\text { 「通信利用動向調查」より) }\end{array}$ & 6,416 万 & 7,813 万 & 1.22 倍 \\
\hline $\begin{array}{c}\text { A/B.インターネット利用者一人当たり } \\
\text { のトラヒック }(a / b)\end{array}$ & $5.29 \mathrm{Kbit} / \mathrm{s}$ & $10.9 \mathrm{Kbit} / \mathrm{s}$ & 2.06 倍 \\
\hline
\end{tabular}

* トラヒックは毎年 11 月, 利用者数は 12 月なので, 集計時期に若干のずれはある.

この結果生じること：ISP の売上げは固定料金制度のため，売上げの伸 びをネットワークコスト増が上回っている（売上げは利用者数に比例す るが, ネットワークコストはピークトラヒックに比例するため).

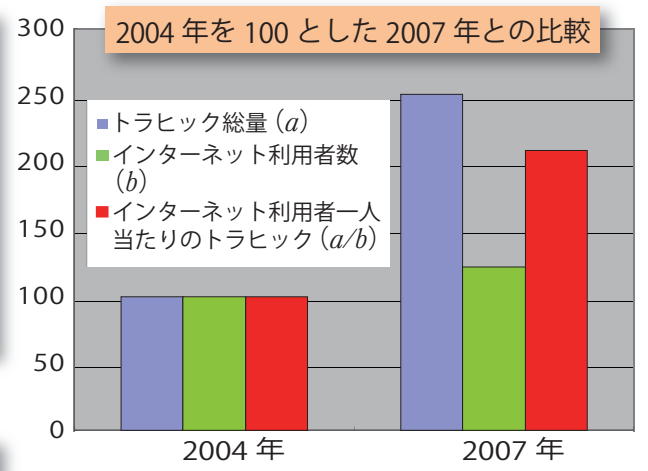

(出典) JAIPA (総務省「インターネット政策懇談会」 第 5 回会合におけるプレゼンテーション資料)

利用者一人当たりのトラヒックは 3 年で約 2 倍の増加.

図 2 利用者一人当たりのトラヒックの拡大 
それがネット混雑という問題である.

我が国のインターネットトラヒック（平均）の推移を見ると， 2008 年 5 月の時点で $880 \mathrm{Gbit} / \mathrm{s}$ に達しており, 前年同期 比で $21.9 \%$ の増加, 過去 3 年間で見ると約 2.1 倍と急激に トラヒック量が増加している[1].

インターネットトラヒックの増加の一つの要因としては, 海外 から国内に流入するトラヒックが極めて多いという点もある. 海外加国内に流入してくるトラヒックは $152.6 \mathrm{Gbit} / \mathrm{s}$ であり, 前年同期比で 31.1\%増となっている. 米国の動画投稿サイ 卜に大量にアクセスしていることが背景にあるだろう。

トラヒックの推移を時間帯別で見てみると, $2004 ０ 7$ 年の 3 年間でトラヒックのピーク / オフピークの比率は 1.8 倍から 2.5 倍へと約 40\%増加している.つまり, 3 年間で卜ラヒックの波動 性が高まっており，ISP はピークトラヒックに合わせた設備増強 が必要になっているものの, 波動性があるがゆえに設備の稼 働率は減少するという状況になっている[2]（図 2).
こうしたインターネットトラヒックの増加は一人当たりのトラ ヒックが増加することによってもたらされている. 過去 3 年間 （2004～ 07 年）でトラヒック $(a)$ は 2.51 倍, PC からのイン ターネット利用者数 $(b)$ は 1.22 倍になっている.つまり, イン ターネット利用者一人当たりのトラヒック $(a / b)$ は 2.06 倍と なっている.

このため, 定額料金制を採用している ISP にとってみると, 加入者数を一定とすると, 売上高は伸びないが卜ラヒック増 に対応するための費用が増加するということになる.

しかし, ネット混雑を生み出しているのはISP ではない. コンテンツプロバイダ, 利用者など広範囲に及んでいる. ISP が設備増強を図るためのコストをだれがどの程度負担すれ ばよいのか(ネットワークのコスト負担の公平性)という問題が 出てきたのである.

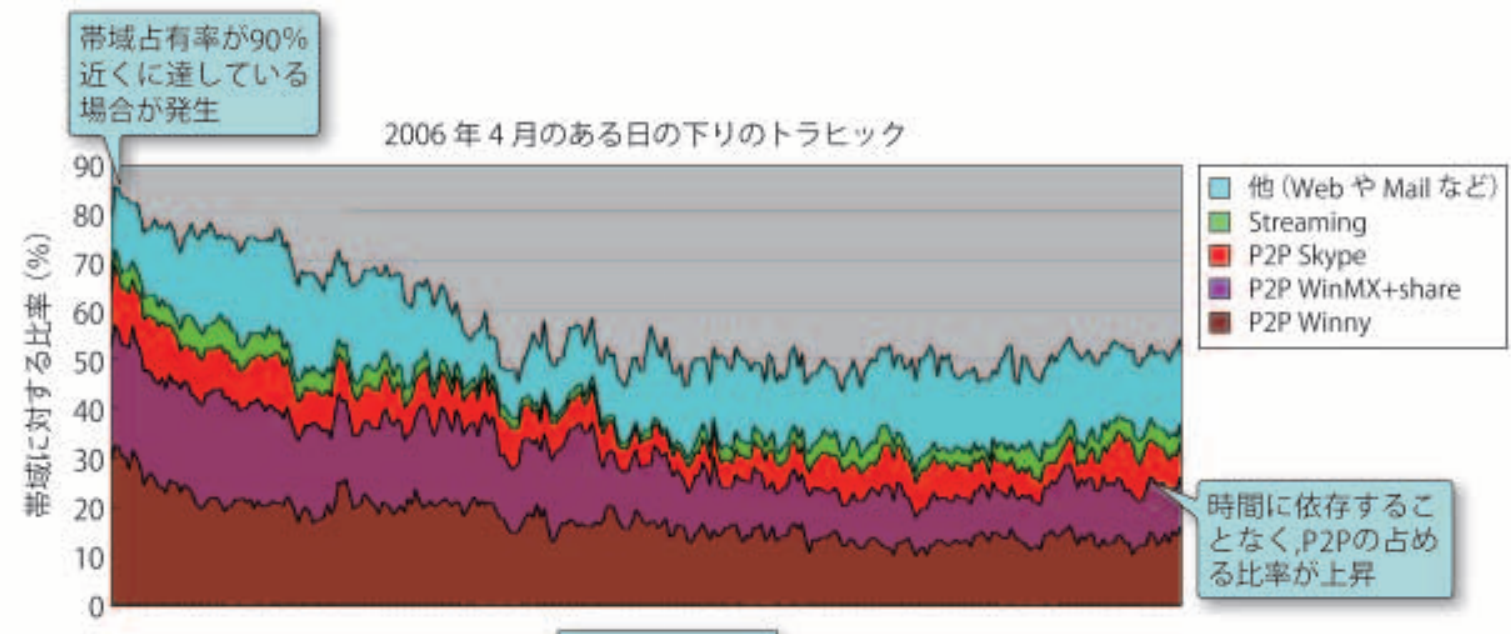

带域占有率は上り ても80\%を上回る 場合が発生

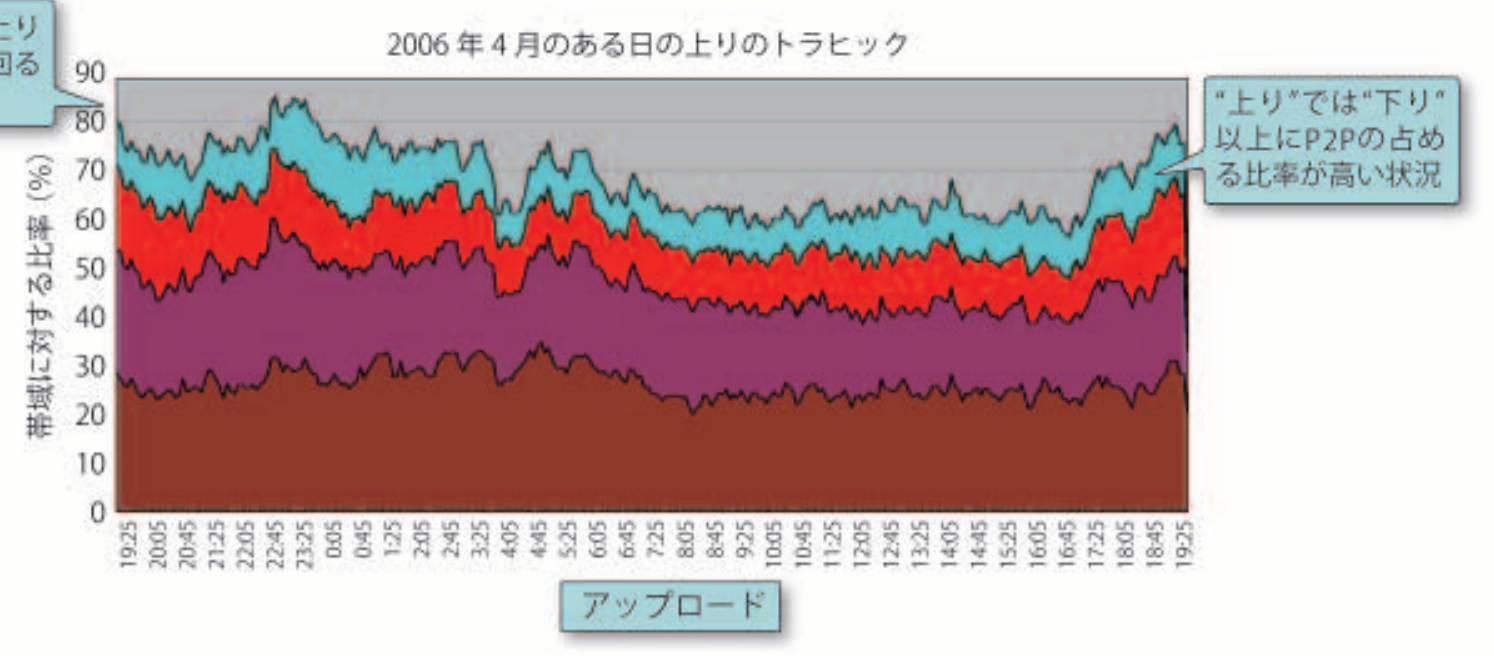

図 3 時間帯別のトラヒックの推移（ある大手プロバイダの例） 


\section{2）ネット混雑の原因 : P2P の光と影}

こうしたネット混雑を生み出している原因は何か. コス卜負 担のあり方に入る前に，そもそもネット混雑への対処があり得 るのかどうかという問題が議論の前提になる.

ある大手プロバイダの時間帯別のトラヒックの推移 を見ると，P2P（Peer to Peer）トラヒックの占有率が高 い. 特に「上り」では「下り」に比べて P2P トラヒックの 占有率が高い.インターネットへの常時接続環境の中 で，特に FTTH（Fiber To The Home）サービスの普及に 伴う上り帯域が拡大することは P2P トラヒックの増加 に大きく貢献しているものと考えられる(図 3).

事実, JAIPA（日本インターネットプロバイダー協会）の資 料によると, インターネッ利用者の 1\%の P2P ユーザが全体 の 60\%以上のトラヒックを生み出している[3]（図 4）.

このように P2P はネット混雑を生み出す要因であるが, 他 方，P2P はネッ混雑を緩和する技術としても活用することが できる.つまり, C/S（Client/Server）型のモデルでは中央の

10\%のユーザが60～90\%のトラヒックを占有

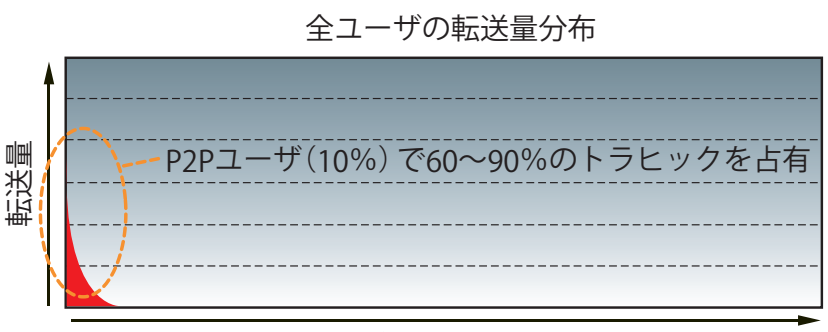

各ユーザ（転送量で昇順）

P2P ユーザ*上位 10\%で 60\%以上のトラヒックを占有

P2P ユーザの転送量分布

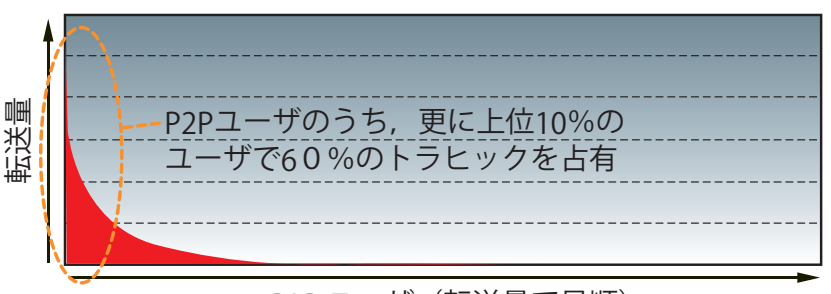

P2P ユーザ（転送量で昇順）

* “P2P ユーザとは 24 時間以内に P2P トラヒックが1MByte 以上あった ユーザとして測定

（出典）総務省「ネットワークの中立性に関する愁談会」第 4 回 P 2P 作業部会 資料(ぷららネットワークス提供) (p.71) (一部抜粋)
配信サーバに配信希望のアクセスが集中すると, サーバは すべての希望をさばききれなくなる，P2Pの場合はトラヒックを 分散させることが可能であり, C/S 型のモデルに比べて効 率的なコンテンツ配信が可能である.

しかし,こうた P2P については Winny に代表される「著 作権侵害」というイメージがこれまで定着しており，効率的な コンテンツ配信を可能にするという「光の面」に注目されるこ とが少なかった：この著作権問題についても技術的にクリア されてきている。

つまり, Winny などの「ピュア型 P2P」の場合, コンテンツ 情報の探索・発見の機能を各ピアが分散して受け持つた め，流通する情報の管理やトラヒック制御を行うことができ ない. 他方, BitTorrentなどが採用している「ハイブリッ゙型 $\mathrm{P} 2 \mathrm{P} 」$ の場合, コンテンツ情報の探索・発見の機能を集中 管理するインデックスサーバを立てる.このため, 情報管理 などを一元的に行うことによって著作権保護の実用に耐え 得るしくみが構築された。

総トラヒックにおけるユーザの分布状況

総トラヒックについて

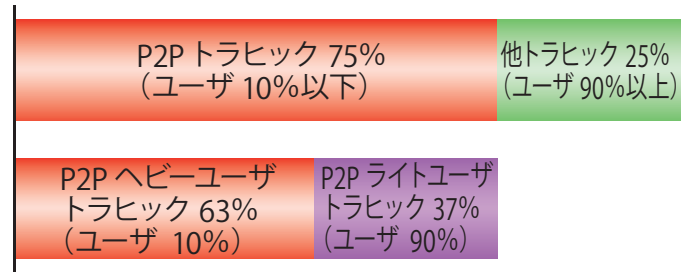

ヘビーユーザと一般ユーザでは使用帯域が大幅に違う 単位ユーザ当たりのトラヒックについて

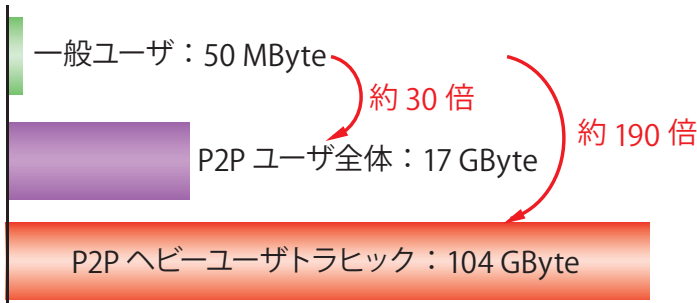

（測定：2003-6-30 12:00〜2003-7-1 11:59)

(注) ぷららネットワークスは 2003 年 11 月から P2P 帯域制御 を行っているため，制御を行わない状況下のデータとして 発表しているのは 2003 年時のものが最新.

\section{P2P ユーザの約 1\%が 6 割以上のトラヒックを生み出している.}

図 4 P2P ユーザのトラヒック使用状況 
このように, P2P はネット混雑を生み出している「影の面」 があるが，逆にこの技術を使うとネッ混雑を緩和するという 「光の面」があり，著作権侵害も防止可能な P2P も登場し てきたことを踏まえ，本格的に $\mathrm{P} 2 \mathrm{P}$ を利用したネット混雑へ の対応（コンテン゙配信の効率性の向上）を図ろうという機 運が高まってきた。

これを受け, 2007 年 8 月,「P2P ネットワーク実験協議会」 が設立され，P2P などのアプリケーション技術を適用した新 たなネットワークサービスの実証実験などを展開している.

$\mathrm{P} 2 \mathrm{P}$ の利点を活用したネッ外混雑の緩和は今後更に効果 を持ってくることが期待されるが, 他方, ネッ混雑の急速 な進展はISP にとって「今そこにある危機」として緊急避難 措置が必要であるという声になってきた。 つまり, 带域制御 (packet shaping)の実施である.

しかし，帯域制御を実施するとしても，特定のコンテンッや アプリケーション，あるいは特定の個人のトラヒックを絞ること は，例えばISP が自分の競争相手である事業者のコンテン ツをねらい撃ちしてトラヒックを絞ることも考えられる。 こうなる と, 改めて公正競争の観点から問題となる.

そこで, 2007 年 9 月, ネッ関連の 4 事業団体が共同して 「帯域制御の運用基準に関する検討協議会」を立ち上げ, 公正な競争を確保しつつ带域制御を行うことを可能とする ためのメルクマール（最低限遵守することが必要な運用基 準)の検討を行い, 2008 年 5 月,「帯域制御の運用基準に 関するガイドラインが策定された。

本ガイドラインでは，(a）P2P ファイル交換ソフトウェアなど 特定のアプリケーションを対象とする带域制御の運用，(b) 一定のトラヒック量を超えたヘビーユーザを対象とした带域 制御の二つに焦点を当てている.

本ガイドラインは, 基本的な考え方として, トラヒックの増加 に対してISP は設備増強によって対処すべきであって, 設 備増強を回避するための帯域制御を否定している。つまり, 帯域制御はあくまで例外的 (緊急避難的)に行われるべきも のであり，その実施に際しては带域制御の対象や程度が 恣意的にならないよう客観的な運用基準に基づくべきである としている.

具体的には, 特定のへビーユーザのトラヒックによってほ かのユーザの円滑なインターネッ利用が妨げられていると いう客観的な状況が存在していることが帯域制御の前提と なる. また, ヘビーユーザの帯域を制御するとしても，一般 ユーザの利用と同程度までの制御は許容されるものの, こ
れを超える制御を行うことは利用の公平性に反するものであ るとしている.

また，本ガイドラインはユーザ保護の観点にも目配りしてい る.つまり, 各 ISPが行う帯域制御の運用方針は, 契約約 款に記載するなどユーザへの十分な情報開示を行うととも に, コンテンツプロバイダやほかの ISP への情報開示も行う ことが重要であるとしている.

このように, ネット混雑の問題は P2P の活用と帯域制御の 実施によって, 一定程度の緩和が可能である。

\section{3）残存するコスト負担の問題}

しかし, ネット混雑への対応は「一定程度の緩和」が可能 なのであって, 問題は依然として残る。

ある大手 ISP が P2P トラヒックに対する帯域制御の実施前 （2005 年）と実施後 (2008 年) の下りトラヒックデータを比べ ると, 実施後はトラヒックの波動性が大きくなり, しかもピーク トラヒックの量は, むしろ帯域制御前を上回る水準となってき ている[4].

つまり，かつては P2Pトラヒックがネット混雑の原因であっ たが, それ以降も動画ストリーミング系のコンテンツ視聴の需 要が高まり，そのトラヒックが急速に拡大している.

JAIPAのデータによると, P2P に対する帯域制御を実施 した, あるISP の全加入者の平均トラヒック（下り，24 時 間）は $172 \mathrm{MByte}$ となっている. 上位 $1 \%$ のヘビーユーザ を除いた平均トラヒックは 84 MByteであり, YouTube 動 画（384 kbit/s） 1 本を視聴するのに要するトラヒックが 14 MByte であることを考えると, 平均 6〜 7 本程度を 1日 視聴しているというのは実感として納得が得られる。逆にい うと, 上位 1\%のユーザのトラヒック量がいかに多いかという ことが想像できる(図 5).

こうした中，改めてへビーユーザに対する課金のあり方が 議論の组上に上ってきた、へビーユーザに対する追加課金 の是非という問題である. 利用者に対する課金のあり方はあ 〈までISP 自らが決定すべきものであるが, 特定の利用者に 対する不当な差別が行われてはならない.

特定のヘビーユーザへの追加課金については, 二つの 面からの検討が必要である. 第一に, ヘビーユーザには円 滑なデー夕伝送を保証して追加収入を得ることができるとい うことは, 高速道路に優先レーンを設けて追加料金を徵収 する形態に似ている. 追加負担をしない一般ユーザは設備 増強の恩恵を受けられず, 追加負担をした場合に初めて 


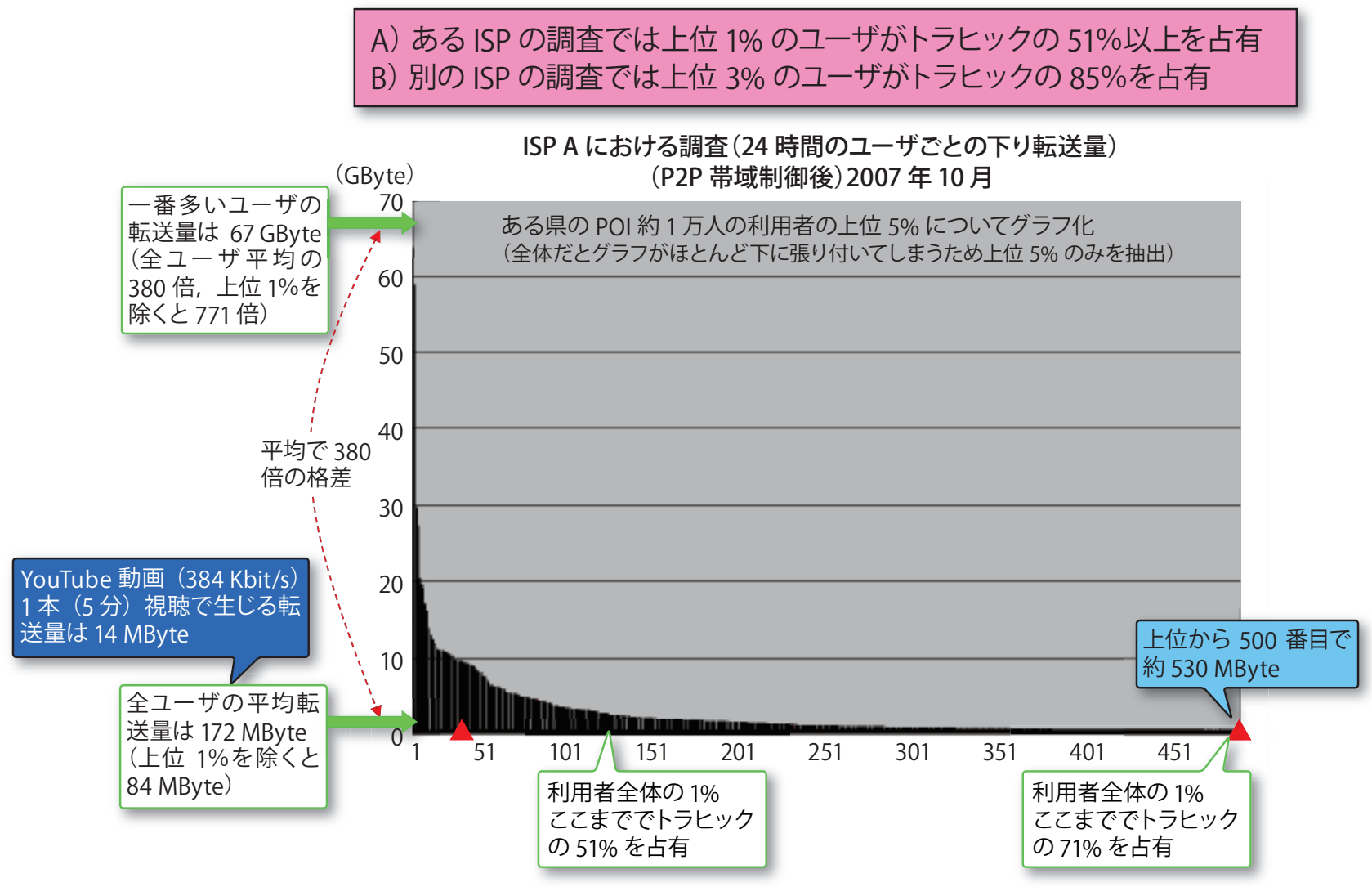

(出典) JAIPA (総務省「インターネット政策懇談会」第5回会合におけるプレゼンテーション資料)

\section{ヘビーユーザと平均的ユーザの間の消費トラヒック格差が極めて大きい.}

図 5 一部利用者によるトラヒックの占有（下り）

設備増強の便益を受け取れるとすると, インターネットにおい てコスト負担をするかしないかで受益度が異なるという「イン ターネットの二層化」が生み出される可能性がある.

第二に, この問題はべストエフォートというインターネットの 基本的な考え方とも密接に関連している.つまり,これまで すべての利用者が同じ定額料金でインターネットを利用でき たのは，ネットワーク運用のコスト減少分がトラヒックの増分を 上回ってきたからこそ実現可能であった，今直面しているの は, トラヒックの増分が逆にネットワークの費用の減少分を上 回るような状況が生まれる可能性があるという問題であると いうことができる. しかし，これも急速な技術革新の中でネッ トワークの運用費用を引き続き抑制できる可能性も存在する が, 少なくとも現時点で確実であるとは言い難い．

このように，ヘビーユーザに対する追加課金については， インターネットそのものの理念に照らして慎重に検討していく 必要がある。

コスト負担の問題のもう一つの検討対象は上位 ISP と下
位 ISP との関係である. 下位 ISP からすると，例えば特定 のコンテンツに人気が集中すると, 上位 ISP から大量のトラ ヒックが流入してくることになる。

上位 ISP の場合，このコンテンツプロバイダと契約してい れば相当の料金を徵収することによりトラヒック処理のコスト はまかなえる. しかし，下位 ISP の立場に立つと，他律的 な要因で大量のトラヒックが流れ込んできても，上位 ISPに 対価を請求することはできない. これは, 対価を払って上位 テイアへの接続（この接続形態は「トランジット (transit)」と呼 ばれる）を確保してもらっており，トラヒックに感応的な精算 をISP 間で行っていないことによる. 仮にトラヒックに感応的 な精算を ISP 間で行うとしても, コス卜的に見て現実的では ない，また，仮に下位 ISP が利用者に追加コスト部分を追 加料金として徵収しようとしても, 利用料金の值上げとなり, ISP 間で激しい競争が行われている現状では, こうした選 択肢を採ることも難しい.

つまり，上位 ISP と下位 ISP との間のコスト負担のあり方 
については明確な解が存在しない，逆にいえば,こうした精 算のしくみが見いだし得ないからこそ，前述の $\mathrm{P} 2 \mathrm{P}$ を活用し たコンテンツ配信の効率化や带域制御の許容という選択肢 が必要になっているといえる.

\section{4. ネットワークの利用の公平性}

\section{1）ネットワークの選択の自由}

2008 年 3 月, NTT 東西は NGN を用いた商用サービ 久を東京・大阪の一部地域で開始した. NGN はインター ネット(the Internet) と同じ IP 網であるが, QoS 及びセキュ リテイを確保するしくみを持つキャリヤによるマネジドネット ワークであると位置づけられる。「自律・分散・協調」を旨と し, ISP が無意識に連携して成長したインターネットとは大き く異なる。

前述のネットワークの中立性に関する 3 原則は,「ネット ワーク=IP 網」を前提としているが，この IP 網は更に二つ のネットワーク，つまり NGN とインターネットに分類することが できる。

NTT 東西が構築する NGN の特徵の一つは, アクセス網 (光ファイバ網) と一体として構築されるという点にある.アク セス系光ファイバ網全体に占めるNTT 東西のシェアは約 7 割である。つまり，利用者にとって NGNを利用する場合で あってもインターネットを利用する場合であっても，文字どおり 「ゲートウェイ」としてNTT 東西の光ファイバ網を経由する 比率が高い，換言すると, NTT 東西はボトルネック設備を保 有しており，いわゆる市場支配力を持っている。仮に NTT 東西が利用者を NGN 内に囲い込むようなこと（市場支配 力の濫用) が行われるとすると, 公正競争は担保されないこ ととなる。

目指すべき世界は NGN とインターネットが共存し, 利用者 は自らの判断でNGN の利用とインターネットの利用を自由に 選ぶことができる環境，つまり「ネットワークの選択の自由」が 保証されることが必要となる，まさにネットワークの利用の公 平性を確保することが求められる。

一般に, ボトルネック設備を保有する市場支配力を持つ 事業者（「ドミナント事業者」と呼ばれる）の場合，保有する ネットワークのオープン化が法律 (電気通信事業法)の規定 によって求められる。

NTT 東西の NGN については, NTT 東西自らが「オー プン化を図る」考えを表明しているが, こうしたオープン性を
担保するため, 接続ルールが適用されている。接続ルール が適用されることにより，NGN との接続において，すべての 接続事業者が同等の条件でNGN を利用できるようにすると ともに, 接続条件についての十分な情報開示が求められる こととなる

なお， NGN それ自体は発展途上のネットワークであること に留意が必要である. このため, 接続ルールの運用は一定 の柔軟性を確保し, 定期的に見直しを行うことにより, 過度 の規制の適用を排除したり，逆に必要な規制の適用を確保 することが求められる. 行政当局においては, 2007 年度か らドミナント事業者（市場支配力を有しており，一定の規律 を適用して他事業者との間の公正競争を確保すべき事業 者）に適用される規制の適正性について定期的に検証する 「競争セーフガード制度」を運用しているところであり, NGN に関する接続ルールについても, このセーフガード制度の枠 組みの中で有効性が検証されている.

\section{2）通信プラットホームのオープン性の確保}

ネットワークの利用の公平性のもう一つの視点は, プラット ホームのオープン性の確保である. 前述のレイヤ構造におい て, プラットホームは, 通信レイヤとコンテンツ・アプリケーション レイヤの間に位置づけられている.

プラットホームの代表例として挙げられるのは認証・課金 機能である. ネッ利用者がコンテンツなどを購入する場合, コンテンツプロバイダなどは購入契約を締結した正当な契約 者であるということを確認(認証)し, コンテンツなどの購入代 金を徵収(課金)する。

こうしたプラットホームは基本的に通信事業者ごとに構築 されている. 例えばモバイルビジネスの場合, 端末販売, 通 信ネットワークの構築, 伝送サービス, インターネッ接続サー ビス, コンテンツポータル (公式ポータル) の提供, 公式ポー タルに揭載するコンテンツの選択などを一体的に提供してい る. その意味でモバイルビジネスはレイヤを縦断する典型的 な垂直統合モデルであるということができる。

2009 年 1 月に公表された総務省「通信プラットフォーム研 究会」報告書 [5] は, こうしたモバイルビジネスにおける認証 基盤のあり方について, 各通信事業者の認証基盤の相互 接続性の確保や, 認証基盤の担い手の多様化を促す方向 で検討することが適当であるとしている.

携带電話事業の場合, 有限希少な電波資源を用いて 行われるビジネスである. このため, 携帯電話事業を展開 
する事業者の数が限られており, 寡占的な市場が形成さ れている.

このため，携帯各社は，垂直統合型の事業モデルの中 で自分だけが提供できる機能を有効に活用し，事業展開し ている面がある。

この垂直統合型のモバイルビジネスにおいては，原則， 公式ポータルに限って, 認証・課金機能が提供されている. つまり, 公式ポータルに掲載されたコンテンツの代金は, 携 带会社が通信サービスの料金の請求とともに加入者に請求 する「料金徵収代行」業務を行っている. しかしながら，公 式ポータル以外のポータルのコンテンツの場合, こうした認 証・課金機能は提供されない. また, 公式ポータルかそれ 以外のポータルであるかの別を問わず，携帯会社以外のプ レーヤが認証・課金機能を提供することは，一部の例外を 除いて事例がない，そして，こうた状況は，葟占的な市場 環境の中で, 携帯会社が経営判断として認めていないため に生じている.

2 章で言及したネットワークの中立性の 3 原則の（c）は, 「消費者が通信レイヤ及びプラットホームレイヤを適正な対 価で公平に利用可能であること」というものであった。 つまり， 利用者が公式ポータルのコンテンツと公式ポータル以外の コンテンツにアクセスする場合に, プラットホームが同じように 利用できるかどうかという点が，ネットワークの中立性の観点 から検討の対象となる。

具体的には, 従来の公式ポータル以外のポータルについ ても携帯会社の認証基盤を提供したり，携帯会社以外のプ レーヤによる認証・課金機能, 具体的にはクレジットカードや 電子マネーでの決済を認める方向で検討することなどを提 言している.

また, 認証基盤の相互接続性の確保は，今後ユビキ夕 スネットワーク環境になっていくうえでますます重要になって くる，想定されるのは，固定・移動のネットワークの別を問わ ず, どのような端末やネットワークからでも共通の認証基盤を 介してコンテンツなどに自由かつ簡単にアクセス可能な環境 の実現である。

前述の NTT 東西の NGN 上には，今後新たに複数の 認証基盤が構築されていくであろうが, こうした認証基盤を モバイル系の通信事業者の認証基盤と相互運用するしくみ （例えば, 各認証基盤の ID を個人の属性情報と切り離し てバーチャルな ID に変換して他事業者に提供するしくみ) が実現すれば，固定ブロードバンドでダウンロードしたコン
テンツを選択し，携带端末で認証・課金するといったことが 可能になる. また, 一つのユーザ ID でネットワークや端末の 違いを超えてコンテンツなどに自由にアクセス可能なしくみの 構築も, 具体的に視野に入ってくる.

このように, ネットワークの利用の公平性という観点からは, 通信事業者が個別に構築してきた認証基盤などのプラット ホームの相互接続性の確保や, こうした機能の担い手を増 やしていくことが必要となってくると考えられる.

\section{5. むす び}

以上見てきたように, ネットワークの中立性は, ブロードバン ド化や IP 化が進展し, 関係するプレーヤが増加する中で, 従来とは異なる枠組みで「本当の公正競争とは何か?」とい うことを問う議論であり, ブロードバンド市場における新しい 競争政策の枠組みを考える議論である. また, 今後のネット ワーク構造の変化をどう考え, インターネットとはそもそも何か, 特に, インターネットの大衆化・産業化という状況の中で「イン ターネットの本質は今後とも維持可能なのか?」という根源的 な問題を提示している面もある.

ネットワークの中立性を巡る議論は, 2005 年頃に米国を 起点としてスタートた [6] が, 各国の置かれている市場環 境などを背景に，それぞれに異なる議論の発展段階をた どっている.

そうした中, 日本におけるネットワークの中立性を巡る議 論は，(a）世界最先端のブロードバンド基盤を有するに至っ ているがゆえに先駆けて具体的な課題に直面していること, （b）ネット混雑論に見られるように，具体的なデー夕に基づ いた議論が行われていること, (c) モバイルビジネスの認証 基盤の相互運用性確保の問題のように, 日本の市場特性 に照らして独自の視点から考えていく必要のある問題が存 在することなどの特徵を持っている.

米国においては, 2009 年 1 月に就任したオバマ大統領 は, 大統領選中の選挙公約 [7]に扔いて「インターネット上の オープンな競争の便益を維持するため, ネットワークの中立 性の原則を強〈支持する」とし，「インターネットが元来持って いるイノベーションと創造性へのオープン性を維持し, 消費 者と民主主義に利益をもたらす自由な言論とイノベーション のための基盤の維持を確保する」ことが必要であるとの考え を示していた. 今後, 米国においても, 改めてネットワークの 中立性を巡る議論が活発化するだろう。 
いずれにせよ，今後のブロードバンド政策を考えていくうえ で，ネットワークの中立性という考え方は基軸となる概念であ る. ネットワークの中立性を基軸として, 今後ともインターネット のあるべき姿について, 包括的で具体的な検討を更に進め ていくことが必要だろう（本稿中，意見などにわたる部分は 著者の個人的な見解です).

\section{文 献}

[1] 総務省, 我が国のインターネットにおけるトラヒッ クの集計・試算, 2008-08-29, http://www.soumu. go.jp/s-news/2008/080829_9.html

[2] 日本インターネットプロバイダー協会, ISP を取り 巻く状況と提案（総務省「インターネット政策懇談 会」第 5 回における提出資料), http://www.soumu. go.jp/joho_tsusin/policyreports/chousa/internet_ policy/pdf/080627_2_si5-2.pdf

[3] 総務省,「ネットワークの中立性に関する懇談会」報告 書，資料 A (資料 19)，2007-09，http://www.soumu. go.jp/s-news/2007/pdf/070920_6_bt-a.pdf

[4]出所は [2] に同じ（以下，本稿におけるデータの 引用は同様)。
[5] http://www.soumu.go.jp/menu_news/s-news/2009/ 090130_3.html

［6］米国におけるネットワークの中立性を巡る議論は, 谷脇康彦, インターネットは誰のものか, 日経 BP 社, 2007-07 を参照.

[7］オバマ米大統領の選挙公約 “Connecting and empowering all Americans through technology and innovation” を参照, http://www.barackobama.com/pdf/issues/ technology/Fact_Sheet_Innovation_and Technology. pdf

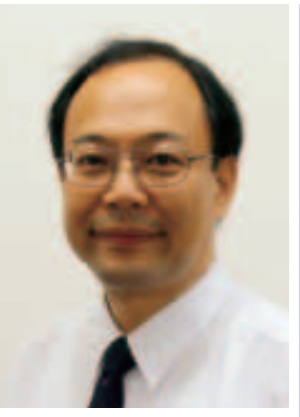

谷脇康彦

昭 59 郵政省（現 総務省）入省. 郵 政大臣秘書官（平 $11 \sim 12$ ），在米日 本大使館参事官（在ワシントン DC）， 総合通信基盤局料金サービス課長, 同事業政策課長などを経て，平 20 年 7 月より総務省情報通信国際戦略局情 報通信政策課長. 著書に「世界一不 思議な日本のケータイ」(インプレス R \& D)，「インターネットは誰のものか」など. Nikkei Net, 日本ビジネスプレスなどへの寄稿多数. 